\title{
COMPARISON OF ELECTROPHORETIC PROTEIN PROFILES OF CAMPYLOBACTER JEJUNI SUBSP. JEJUNI ISOLATED FROM DIFFERENT ANIMAL SPECIES
}

\author{
Eliana Scarcelli $^{1 *}$; Elizabeth Oliveira da Costa ${ }^{2}$; Margareth Élide Genovez ${ }^{1}$; Maristela Vasconcellos Cardoso ${ }^{1}$; \\ Erna Elizabeth Bach ${ }^{3}$; Ana Paula Torres ${ }^{1}$ \\ ${ }^{1}$ Centro de Sanidade Animal, Instituto Biológico, São Paulo, SP, Brasil; ${ }^{2}$ Faculdade de Medicina Veterinária e Zootecnia, \\ Universidade de São Paulo, São Paulo, SP, Brasil; ${ }^{3}$ Centro de Biotecnologia, Instituto Biológico, São Paulo, SP, Brasil
}

Submitted: January 16, 2001; Approved: October 11, 2001

\begin{abstract}
Electrophoretic protein profiles of Campylobacter jejuni subsp. jejuni strains isolated from feces of seven animal species, including man, were compared. Fourteen strains (two from each species) plus two human strains and the reference one, were ruptured by ultrasound and their total soluble proteins were analyzed by SDS-PAGE technique in a $12 \%$ polyacrylamide gel with computerized densitometric reading by the molecular analyst software. All the strains had bands in common that correspond to 45 and $66 \mathrm{Kda}$ molecular weight. The disagreement corresponded to a 97 to $200 \mathrm{Kda}$ molecular weight region. From the 17 strains, 13 (76.5\%), were classified as biotype I, three (17.6\%) as biotype II and one (5.8\%) as biotype III. Since protein extracts were obtained from cells grown under identical conditions, and thus, able to express the same phenotype, this disagreement region could be related to different genotypes or serotypes.
\end{abstract}

Key words: Campylobacter jejuni, SDS-PAGE, biotyping.

\section{INTRODUCTION}

Bacteria of the genus Campylobacter are widely distributed in nature, and are found in several domestic and wildlife animal species, causing a large number of diseases that may vary from abortion and infertility to enteritis and mastitis. Sometimes they are found only as commensal microorganisms (7).

It was only two decades ago that intestinal campylobacteriosis was recognized as an important zoonosis, and this lead to the occurrence of a great number of studies $(15,18)$. Although the majority of the cases are related to limited diarrhea, a severe sequel represented by reactive arthritis and Guillain-Barre syndrome may sporadically occur (1). In human beings, the infection source is attributed to direct contact with carrier animal, to the consumption of contaminated water and animal origin food. It is mainly caused by the ingestion of non-pasteurized milk and poorly processed poultry meat. Approximately four million cases of human campylobacteriosis occur each year in the United States $(1,16)$.
Polyacrylamide gel electrophoresis of bacterial proteins has been used as an efficient technique for the classification of microorganisms, based on phenotipical characteristics expressed by their protein profiles. Bacterial groupings based on electrophoretic profile correlate very well with the results obtained by the DNA hybridization $(8,14)$.

The establishment of an epidemiological chain to link more precisely human infection to animal contact or transmission by food may be reached by the use of markers (10).

The objective of this report was to compare the electrophoretic protein profiles of Campylobacter jejuni strains isolated from feces samples of different animal species and man.

\section{MATERIALS AND METHODS}

\section{Strains of Campylobacter jejuni for the comparative study}

Fourteen strains of Campylobacter jejuni were isolated from feces of seven animal species (bovine, swine, canine, feline, primate, chicken and sheep). Two strains of each animal species,

\footnotetext{
* Corresponding author. Mailing address: Centro de Sanidade Animal, Instituto Biológico, Av. Conselheiro Rodrigues Alves, 1252. 04014-002, São Paulo, SP, Brasil. Tel.: (+5511) 5087-1770, E-mail: pinheiro@biologico.br
} 
were processed at the Centro de Sanidade Animal do Instituto Biológico de São Paulo - Brazil to be used. The two strains of Campylobacter jejuni isolated from human cases were provided by Instituto Adolfo Lutz, São Paulo - Brazil, and the Campylobacter jejuni reference strain was provided by the National Enteric Reference, Center for Diseases Control, Canada, registered as 913/PC-264, as presented in Table 1.

\section{Biotyping}

The 16 previously selected strains and the reference strain were biotyped using the scheme by Lior, 1984 (10), that recognizes four biotypes (I, II, III and IV) of C. jejuni, based on the tests of hippurate hydrolysis, rapid $\mathrm{H}_{2} \mathrm{~S}$ test and DNA hydrolysis.

\section{Rupture of the bacterial cells by ultra-sound}

Each of the 17 strains was inoculated in Brucella agar (Difco) supplemented with $10 \%$ of sheep blood and incubated at $37 \mathrm{oC}$, in an atmosphere of $85 \% \mathrm{~N}_{2}, 10 \% \mathrm{CO}_{2}$ and $5 \% \mathrm{O}_{2}$, for 48 hours (17). These conditions were standardized for all cultures. Bacterial cells were harvested in $5 \mathrm{ml}$ of $0.15 \mathrm{M}$ Tris- $\mathrm{HCl}$ buffer, $\mathrm{pH} 7.0$ (14). After centrifugation at $8.000 \mathrm{x}$ g for 30 minutes in a refrigerated centrifuge (Sed-20), sedimented cells were resuspended in $3 \mathrm{ml}$ of the same buffer to obtain the optical density of Tube 3 in Mac Farland's scale. The bacterial cells were disrupted by ultra-sound (T7-Thornitron) at $60 \mathrm{~Hz}$ for 12 minutes. The mass was centrifuged once again at $8.000 \mathrm{x} \mathrm{g}$ for 20 minutes. Protein concentration of the supernatant was estimated by a standard kit (BCA - Pierce) and read in a spectrophotometer (Hitachi) at $560 \mathrm{~nm}$ absorbancy.

The final concentration of each sample was adjusted to contain $1 \mathrm{mg} / \mathrm{ml}$ of soluble protein.

\section{Polyacrylamide electrophoresis gel}

Preparation of strains for SDS-PAGE and running of the samples was performed as previously described $(6,9,19)$. Electrophoresis was carried out in $12 \%$ acrylamide running gel and a $4 \%$ stacking gel, with $0.025 \mathrm{M}$ tris $0.19 \mathrm{M}$ glycine buffer $\mathrm{pH}$ 8.3. Samples of $50 \mu \mathrm{l}$ of each sonicated strain and of $10 \mu \mathrm{l}$ of the molecular weight marker (Bio-Rad), were loaded into sample wells. Electrophoresis was performed at $25^{\circ} \mathrm{C}$ in a vertical tank apparatus maintained at $100 \mathrm{~V}$ using a constant-voltage power supply, until bromophenol blue tracking dye reached the bottom of the gel. Gels were submitted to TCA (trichloroacetic acid) at $10 \%$ for 1 hour at $4^{\circ} \mathrm{C}$, and them stained with $0.25 \%$ Coomassie Brilliant Blue R-250 (Bio-Rad) in water-methanolacetic acid (6.5:2.5:1) for 18 hours at room temperature. They were destained by agitation in solvent (30:7:63 v/v/v) plus 3\% of glycerol (Merck) submitted to several changes until the moment of drying (4).

\section{Densitometry}

Gels were transferred to cellophane paper and dehydrated in a gel dryer apparatus (model 583 - Bio-Rad) at $80^{\circ} \mathrm{C}$, for 24 hours and after that they were scanned using a densitometer (model GS-700 - Bio-Rad) programmed with the "Molecular Analyst" software (Bio-Rad), at $560 \mathrm{~nm}$ absorbancy.

\section{RESULTS}

From 17 strains analyzed, $13(76,5 \%)$ were characterized as biotype I: H1, H2, S1, S2, F1, F2, O1, O2, C1, C2, G1, G2 and B1; three $(17,6 \%)$ as the biotype II: M1, M2, R and one $(5.8 \%)$ as biotype III: B2. Biotype IV was not observed.

Table 1. Relation of the Campylobacter jejuni strains according to the identification, the origin and the source.

\begin{tabular}{|c|c|c|}
\hline Identification & Origin & Source \\
\hline H1 = Human 1 & Human (masculine sex, 2 years old) & São Paulo-SP \\
\hline H2 = Human 2 & Human (masculine sex, 38 years old) & São Paulo-SP \\
\hline M1 = Monkey 1 & Lion-tamarins (male-adult) & São Paulo-SP \\
\hline M2 = Monkey 2 & Lion-tamarins (male-adult) & São Paulo-SP \\
\hline $\mathrm{S} 1=$ Swine 1 & Swine (male-adult) & Itú-SP \\
\hline $\mathrm{S} 2=$ Swine 2 & Swine (male-adult) & Itapecerica da Serra-SP \\
\hline F1 = Chicken 1 & Chicken (48 days) & São Carlos-SP \\
\hline $\mathrm{F} 2=$ Chicken 2 & Chicken (48 days) & Descalvado-SP \\
\hline B1 = Bovine 1 & Bovine (female-adult) & Caçapava-SP \\
\hline $\mathrm{B} 2=$ Bovine 2 & Bovine (female-adult) & Cambuí-MG \\
\hline O1 = Sheep 1 & Sheep (male-adult) & Vitória-ES \\
\hline $\mathrm{O} 2=$ Sheep 2 & Sheep (male-adult) & Vitória-ES \\
\hline $\mathrm{C} 1=\operatorname{Dog} 1$ & Dog (male-adult) & São Paulo-SP \\
\hline $\mathrm{C} 2=\operatorname{Dog} 2$ & Dog (male-adult) & São Paulo-SP \\
\hline $\mathrm{G} 1=\mathrm{Cat} 1$ & Cat (male-adult) & São Paulo-SP \\
\hline $\mathrm{G} 2=\mathrm{Cat} 2$ & Cat (male-adult) & São Paulo-SP \\
\hline
\end{tabular}


Figs. 1 and 2 show the protein profile of the 17 Campylobacter jejuni strains separated by a $12 \%$ SDS-PAGE and stained by Coomassie Blue 250R.

Figs. 3 to 11 show the densitometer scans of the gels from the 17 disrupted Campylobacter jejuni subsp. jejuni strains. These strains presented distinctive bands positioned in various points of each lane. Bands in the 3.3-3.6 cm, 5.1-5.7 cm, and 5.8$6.5 \mathrm{~cm}$ regions were common to all strains. The $3.6-3.8 \mathrm{~cm}, 3.8-$ $4.1 \mathrm{~cm}$ and $6.5-7.0 \mathrm{~cm}$ regions were also the same for all the strains with the exception of the "atypical" O2 strain, which presented fewer bands than the others. The homologous region corresponds to a 45 and $66 \mathrm{Kda}$ molecular weight which could be species- or genus-specific. The different regions corresponded to a 97 to $200 \mathrm{Kda}$ molecular weight.

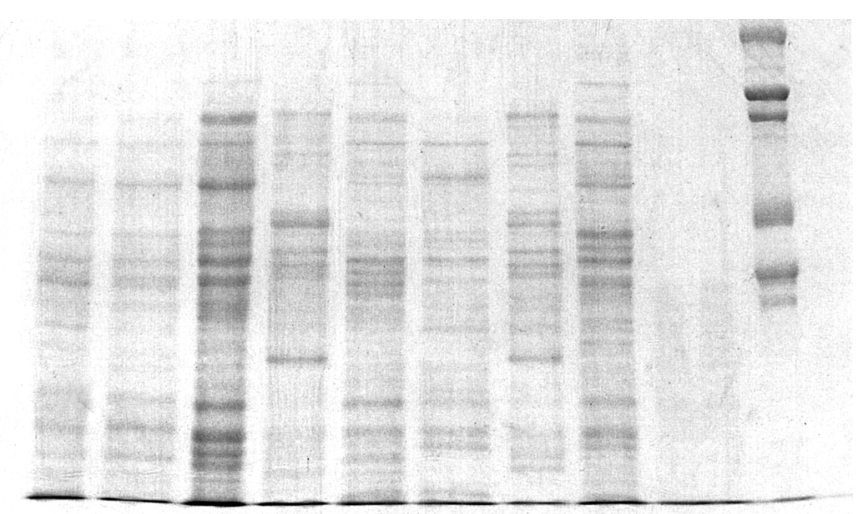

Figure 1. 12\% SDS-PAGE showing protein bands of $C$. jejuni strains, stained by Coomassie Blue. Lanes: F2 $=$ Chiken 2, F1= Chiken 1, S2= Swine 2, S1= Swine 1, M2= Monkey 2, M1= Monkey 1, H2= Human 2, H1= Human 1, R= Reference strain and MW= Molecular weight standard

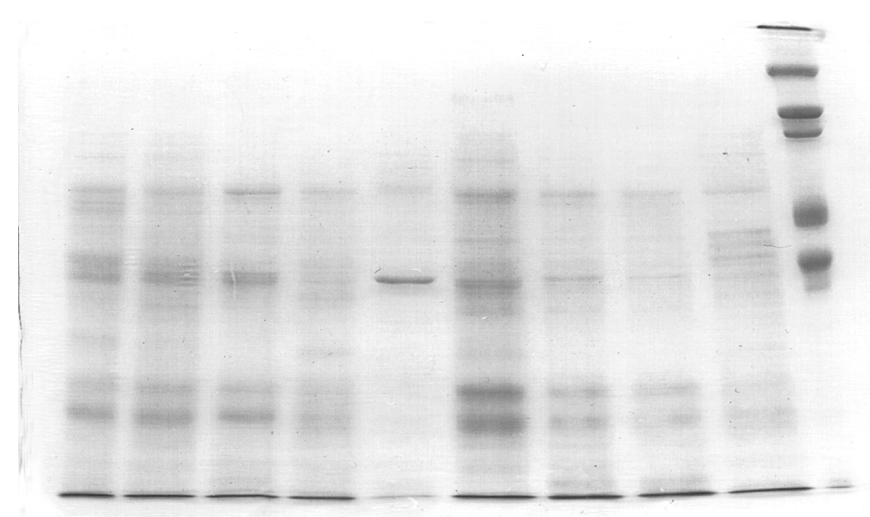

Figure 2. 12\% SDS-PAGE showing protein bands of $C$. jejuni strains, stained by Coomassie Blue. Lanes: $\mathrm{G} 2=\mathrm{Cat} 2, \mathrm{G} 1=\mathrm{Cat}$ $1, \mathrm{C} 2=\operatorname{Dog} 2, \mathrm{C} 1=\operatorname{Dog} 1, \mathrm{O} 2=$ Sheep 2, O1= Sheep 1, B2= Bovine $2, \mathrm{~B} 1=$ Bovine $1, \mathrm{R}=$ Reference strain and $\mathrm{MW}=$ Molecular weight standard.

\section{DISCUSSION}

The increase in the isolation of Campylobacter strains from human diarrheal disease and the high rate of carrier animals, as poultry and swine, have demonstrated the necessity of marker characterization and identification to support epidemiological investigations (11).

Protein electrophoretic analysis of Campylobacter spp in polyacrylamide gel in the presence of SDS (SDS-PAGE) supplies data that can be used in epidemiological and taxonomic studies; it also aids the identification of species and specific virulence factors (2).

Moore et al. (13) using protein electrophoresis demonstrated that bacteria isolated from oral cavity could be distinguished by their electrophoretic migration patterns, pointing out the potential application of this technique in ecological and epidemiological studies, mainly in the identification of multiple isolations from one clinical specimen.

Ferguson et al. (4) demonstrated the possibility of differentiation of Campylobacter species by the analysis of
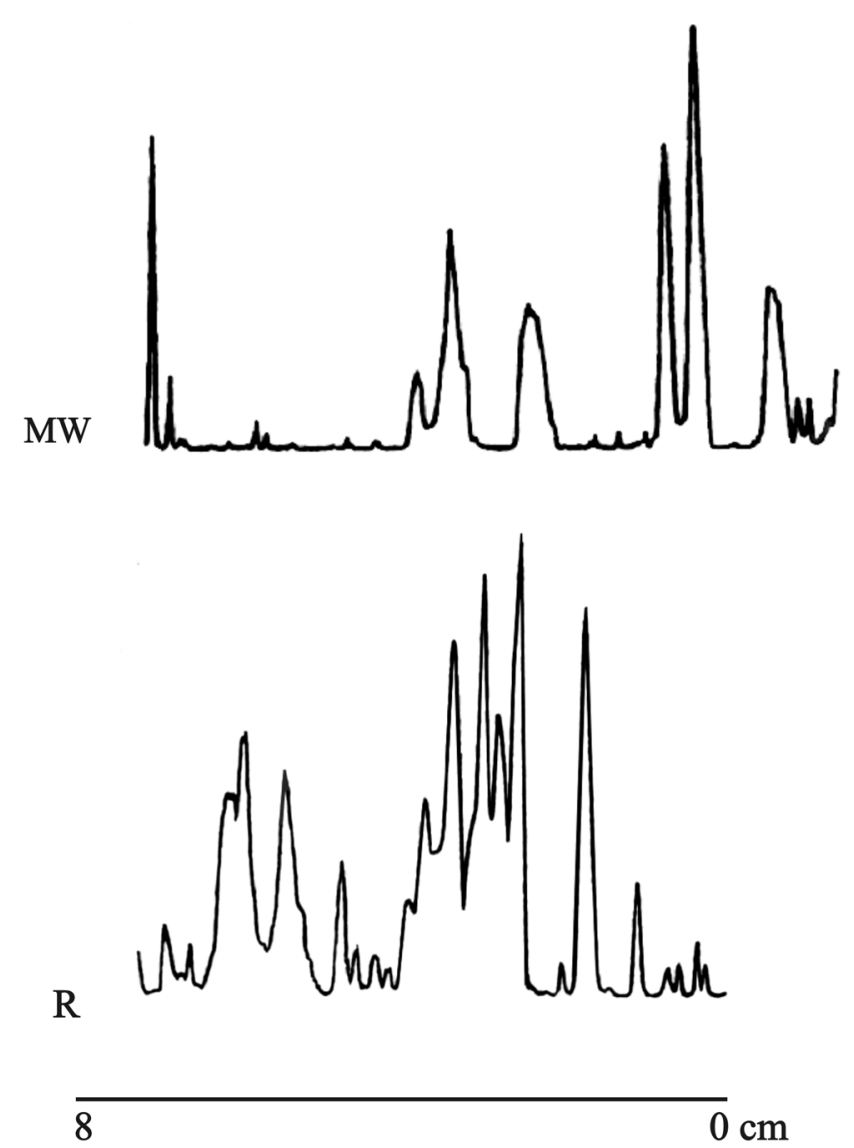

Figure 3. Densitometer scan of the molecular weight standard (MW) and C. jejuni reference strain (R), stained by Coomassie Blue. 


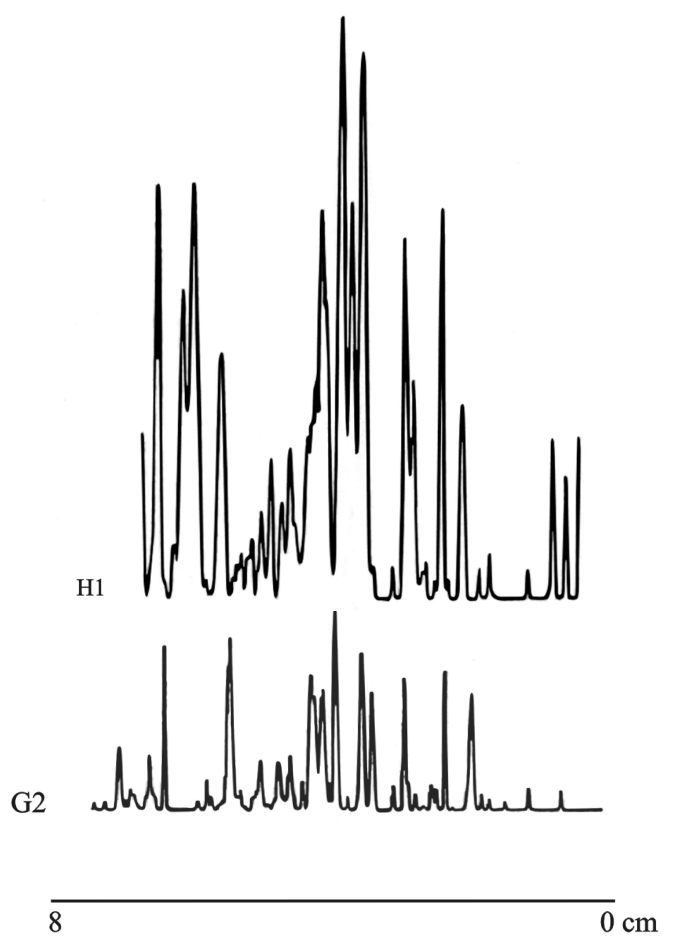

Figure 4. Densitometer scan of the $C$. jejuni proteins from Human 1 (H1) and Human 2 (H2) samples, stained by Coomassie Blue.

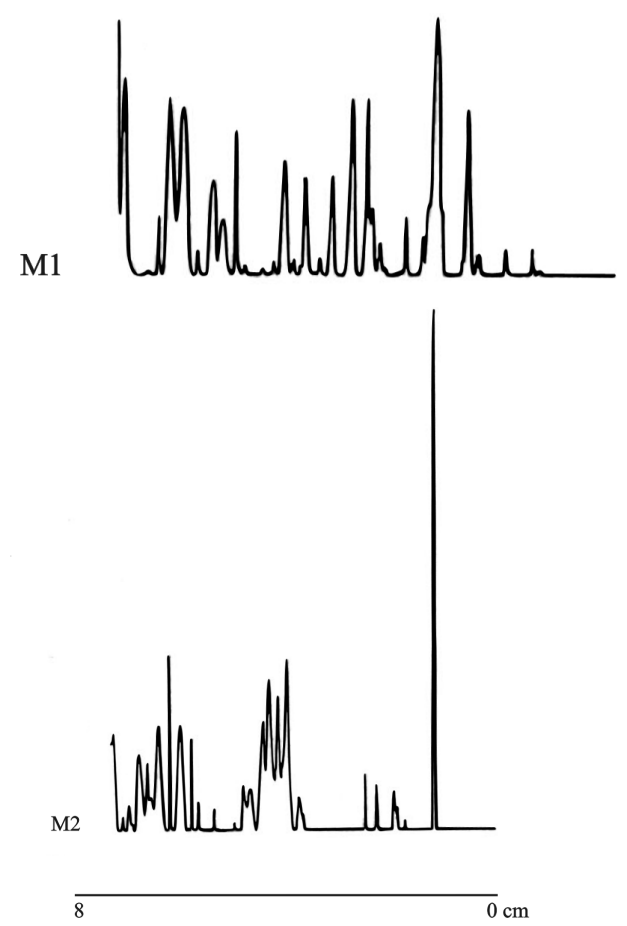

Figure 5. Densitometer scan of the $C$. jejuni proteins from Monkey 1 (M1) and Monkey 2 (M2) samples, stained by Coomassie Blue.

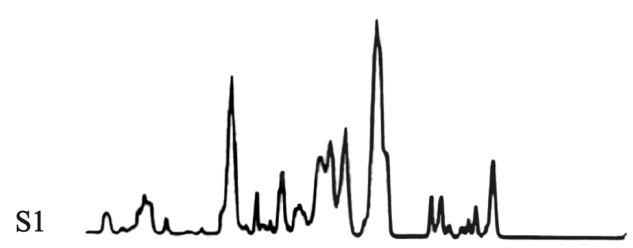

S2

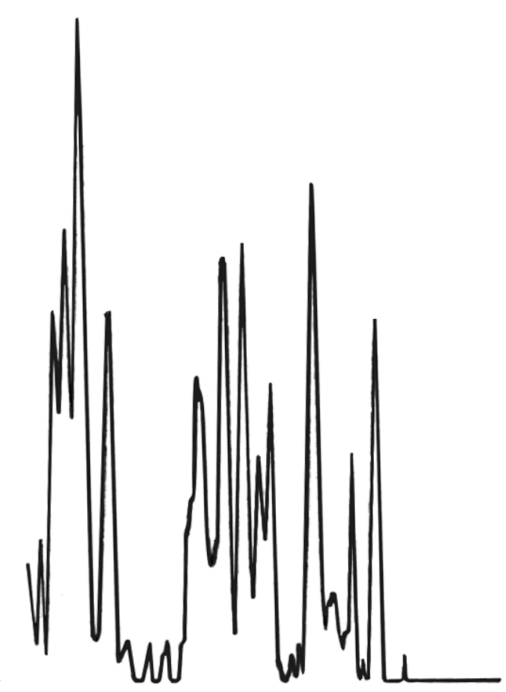

Figure 6. Densitometer scan of the $C$. jejuni proteins from Swive 1 (S1) and Swive 2 (S2) samples, stained by Coomassie Blue.

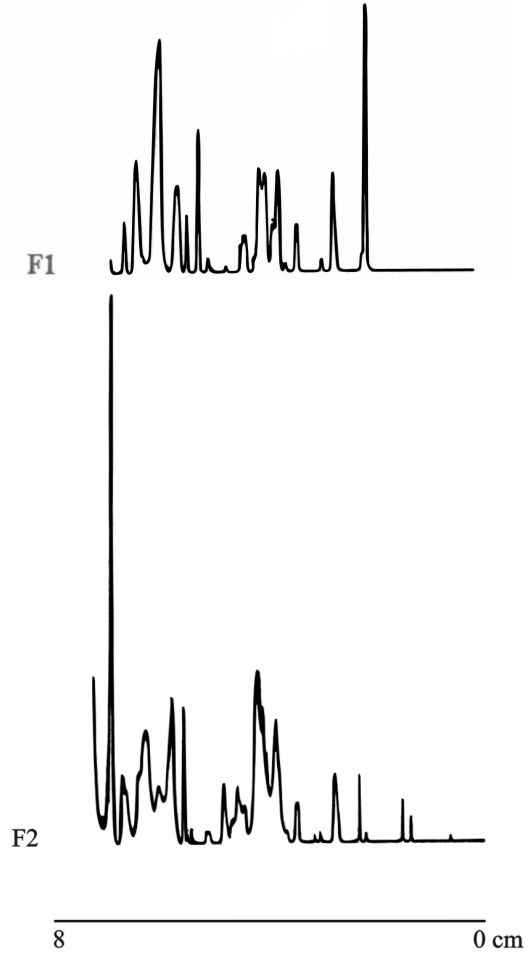

Figure 7. Densitometer scan of the $C$. jejuni proteins from Chicken 1 (F1) and Chicken 2 (F2) samples, stained by Coomassie Blue. 

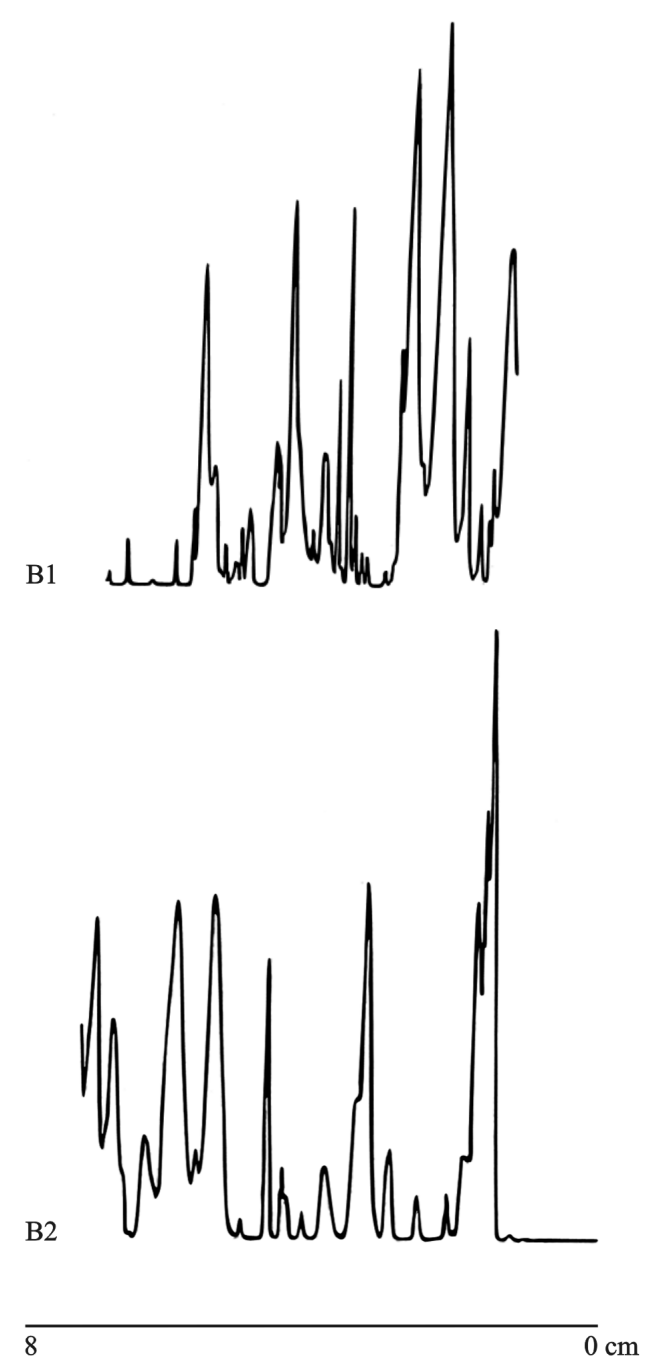

Figure 8. Densitometer scan of the $C$. jejuni proteins from Bovine 1 (B1) and Bovine 2 (B2) samples, stained by Coomassie Blue.

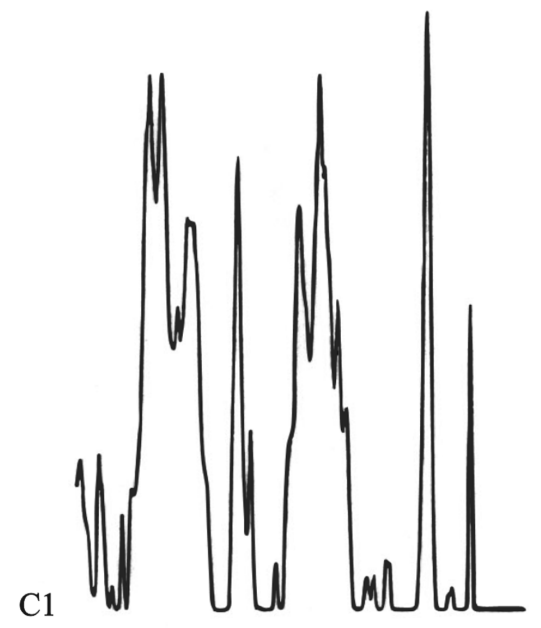

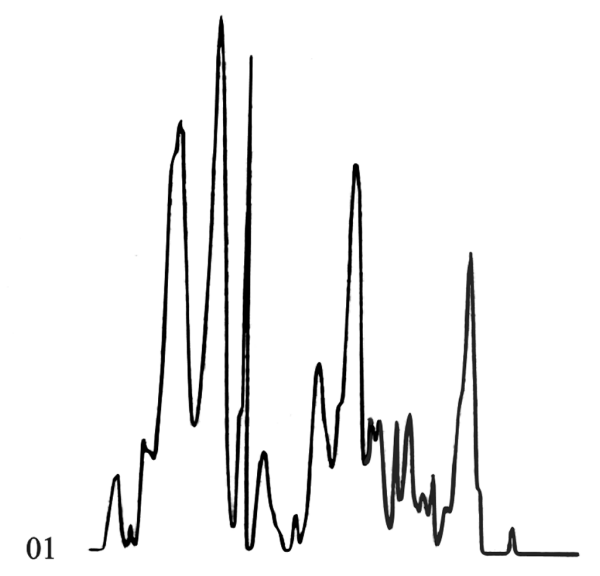

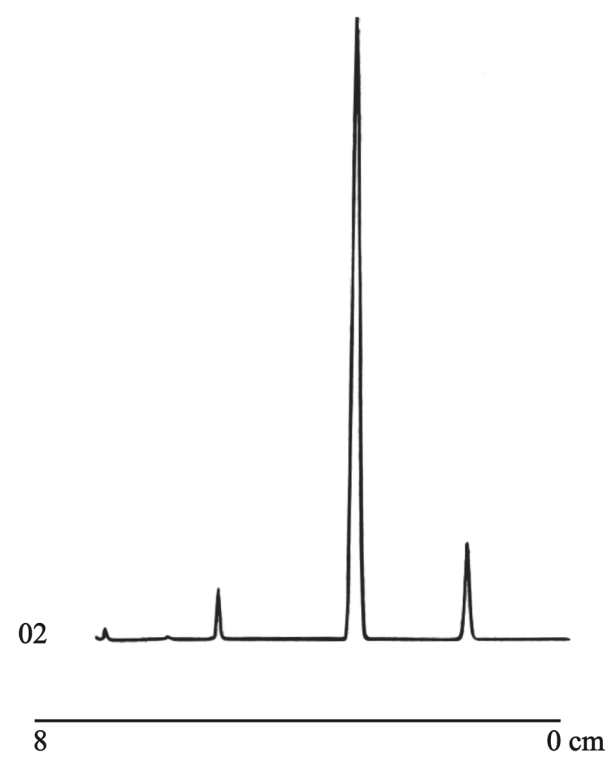

Figure 9. Densitometer scan of the C. jejuni proteins from Sheep 1 (O1) and Sheep $2(\mathrm{O} 2)$ samples, stained by Coomassie Blue.

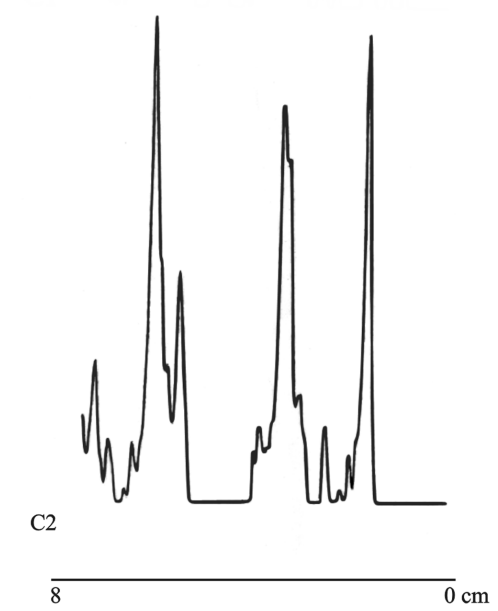

Figure 10. Densitometer scan of the C. jejuni proteins from Dog 1 (C1) and Dog 2 (C2) samples, stained by Coomassie Blue. 


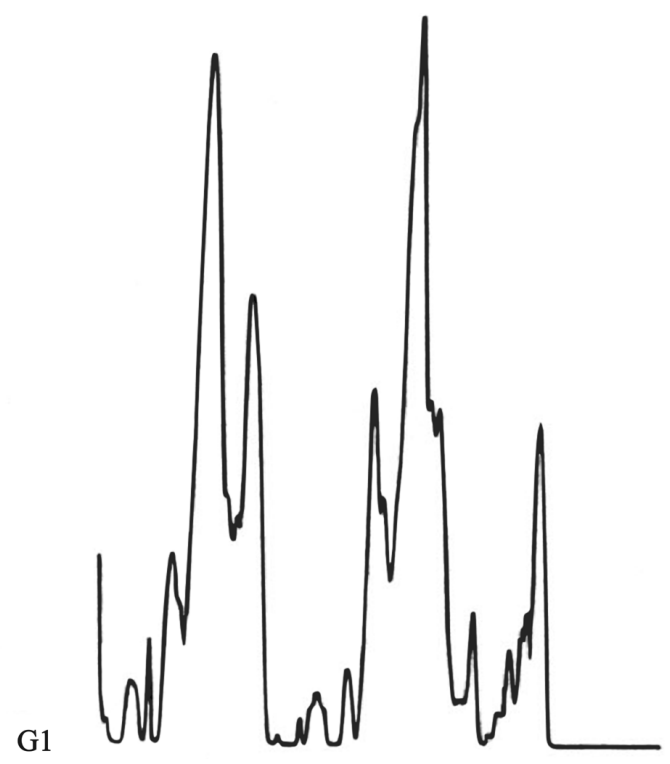

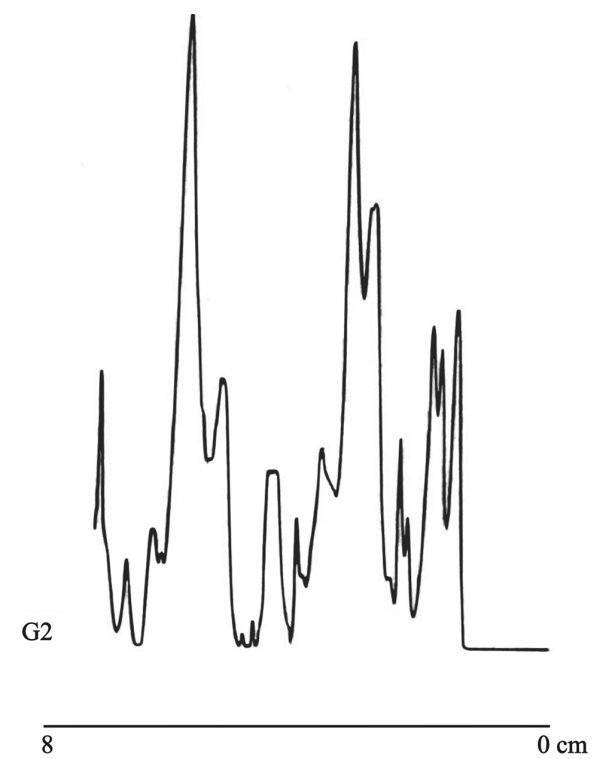

Figure 11. Densitometer scan of the $C$. jejuni proteins from Cat 1 (G1) and Cat 2 (G2) samples, stained by Coomassie Blue. their patterns in polyacrylamide gel, and postulated that there is a correlation among the electrophoretic migration pattern of soluble proteins, the phenotypic characteristics and DNA homology.

In the present study it was observed that strains presented bands positioned in common regions and in different areas, independently of the origin of the strain, with the exception of $\mathrm{O} 2$ strain. When the positions of the band were compared to the molecular weight standard, it was found that the $66.2 \mathrm{Kda}$ and $45 \mathrm{Kda}$ regions were common to all strains, with exception of $\mathrm{O} 2$ strain. The common region could be related to species- or genus-specific proteins, and these results suggest that these proteins would be porine $(45 \mathrm{Kda})$ and flageline $(60 \mathrm{Kda})$, respectively, as found by McSweegan and Walker (12) and Fauchère et al. (3).

Ohya et al. (14), comparing two different species isolated from swine, $C$. hyointestinalis and $C$. mucosalis, using the protein electrophoretic profiles, observed areas producing common bands in the two bacteria species, and areas producing different bands, that could be used to differentiate one from the other. However, they were not able to detect differences between the electrophoretic patterns of $C$. hyointestinalis isolated from swine and bovine. These authors observed differences in the electrophoretic patterns of serotypes A, B and C of C. mucosalis strains, which are probably related to the antigenic diversity.

Jarvis and Wolff (8) applied the protein electrophoresis with densitometric analysis to Streptococcus spp strains isolated from milk, comparing them according to their degrees of similarity. They suggested that the strains that were considered to be similar, when cultivated under the same conditions, presented homologous phenotypes, which consequently corresponded the same genotype. Those authors observed that small phenotypic variations, as some biochemical characteristics, were not revealed by the SDS-PAGE technique, unless there are great differences in the phenotypes of these microorganisms. Accordingly, the results obtained with this technique applied to Campylobacter jejuni strains, was not able to discriminate one biotype from the other .

Since protein extracts were obtained from cells grown under identical conditions, and thus, able to express the same phenotype, this disagreement region could be related to different genotypes or serotypes.

\section{RESUMO}

\section{Comparação dos perfis eletroforéticos de proteínas de Campylobacter jejuni subsp. jejuni isoladas de diferentes espécies animais.}

Perfis eletroforéticos de proteínas de cepas Campylobacter jejuni subsp. jejuni isoladas de fezes de diferentes espécies animais, inclusive o homem, foram comparados. Quatorze cepas (duas de cada espécie) mais duas cepas de origem humana e a cepa de referência foram rompidas por ultra-som e suas proteínas solúveis totais analisadas através das técnicas de SDS-PAGE em gel de poliacrilamida a $12 \%$ e análise densitométrica. Todas as cepas tinham em comum bandas que migraram em regiões que correspondiam ao peso molecular de 45 e $66 \mathrm{Kda}$. As regiões discordantes correspondiam principalmente às regiões entre 97 e $200 \mathrm{Kda}$. Das 17 cepas, 13 (76.5\%), foram classificadas como 
biotipo I, três (17.6\%) como biotipo II e uma (5.8\%) como biotipo III. Uma vez que os extratos de proteínas foram obtidos de células que se desenvolveram sob condições idênticas, possibilitando a expressão do mesmo fenótipo, estas regiões protéicas discordantes poderiam estar relacionadas a diferentes sorotipos ou genótipos.

Palavras-chave: Campylobacter jejuni, SDS-PAGE, biotipagem

\section{REFERENCES}

1. Altekruse, S.F.; Swerdlow, D.L.; Stern. N.J. Campylobacter jejuni. Vet. Clin. North Am. Food Anim. Pract., 14: 31-40, 1998.

2. Dunn, B.E.; Blaser, M.J.; Snyder, E.L. Two dimensional gel electrophoresis and immunoblotting of Campylobacter outer membrane proteins. Infect. Immun., 55: 1564-1572, 1987.

3. Fauchère, J.L.O.; Kervella, M.; Rosenau, A.; Mohanna, K.; Vèron, M. Adhesion to HeLa cells of Campylobacter jejuni and Campylobacter coli outer membrane components. Res. Microbiol., 104: 379-92, 1989.

4. Ferguson, D.A.; Lambe, D.W. Differentiation of Campylobacter species by protein banding patterns in polyacrylamide slab gels. $J$. Clin. Microbiol., 20: 453-460, 1984.

5. Fujimoto, S.; Fujita, M. Serum antibody level against GroEL type heat-shock protein of Campylobacter jejuni in patients with GuillainBarre syndrome. Microbiol. Immunol., 43(3): 241-242, 1999.

6. Hames, B.D.; Rickwood, D. Gel electrophoresis of proteins. A practical approach, Oxford University Press, New York, 1990, 323p.

7. Holt, J.G.; Krieg, N.R.; Sneath, P.H.A.; Staley, J.T.; Williams, S.T. Bergey's manual of determinative bacteriology. 9.ed. Baltimore: Williams \& Wilkins, 1994, 787p.
8. Jarvis, A.W.; Wolff, J.M. Grouping of lactic streptococci by gel electrophoresis of soluble extracts. Appl. Environ. Microbiol., 37: 391-398., 1979.

9. Laemmli, U.K. Cleavage of structural proteins during the assembly of the head of bacteriophage T4. Nature., 227: 680-685, 1970.

10. Lior, H. New extended biotyping scheme for Campylobacter jejuni, Campylobacter coli and "Campylobacter laridis". J. Clin. Microbiol., 20: 636-640, 1984.

11. Lior, H. Campylobacters - epidemiological markers. Dairy Food Environ. Sanit. 14: 317-324, 1994

12. McSweegan, E.; Walker, R.I. Identification and characterization of two Campylobacter jejuni adhesins for celular and mucous substrates. Infect. Immun., 53: 141-148, 1986.

13. Moore, W.E.C.; Hash, D.E.; Holdcfeman, L.V.; Cato, E.P. Polyacrylamide slab gel electrophoresis of soluble proteins for studies of bacterial floras. Appl. Environ. Microbiol. 39: 900-907, 1980.

14. Ohya, T.; Kubo, M.; Watase, H. Electrophoretic protein patterns in Campylobacter species with special reference to Campylobacter mucosalis and Campylobacter hyointestinalis. Jpn. J. Vet. Sci., 50: 692-698, 1988.

15. Penner, J.L. The genus Campylobacter: a decade of progress. Clin. Microbiol. Rev., 1: 157-72, 1988.

16. Perez-Perez, G.I.; Blaser, M.J. Campylobacter and Helicobacter, In: S. Baron (Editors.) Med. Microbiol. Churchill Livingstone, New York, p.337-349, 1991.

17. Scarcelli, E.; Genovez, M.E.; Rojas, S.; Bersano; J.G.; Schotten, M.H.S.S. Avaliação da presença de Campylobacter spp em suínos: sua relação com a ocorrência de distúrbios entéricos. Rev. Microbiol., 22: 112-115, 1991.

18. Smibert, R.M. Genus Campylobacter. In: KRIEG, N.R. and HOLT, H.G. (Editors.) Bergey's Manual of systematic bacteriology. The Willians \& Wilkins Co., Baltimore, Md, 1984, p.111-118.

19. Witaker, J.R. Electrophoresis in stabilizing media. Academic Press, New York, 1967, 420p. 